\title{
Hospital Statistics as a Tool for Obtaining Data Necessary in the Healthcare Entity Management Process
}

\author{
Aleksandra Sierocka ${ }^{1}$, Bożena Woźniak ${ }^{1}$, Petre Iltchev ${ }^{2}$, \\ Michał Marczak ${ }^{2}$ \\ ${ }^{1}$ K. Jonscher Hospital in Lodz, Poland \\ 2 Health Care Policy Department, Medical University in Lodz, Poland
}

\begin{abstract}
Statistical methods used by healthcare entities enable the collection of various information about the structure and characteristics of treated patients. They are an important source of knowledge, and form a database that plays an important role in entity management theory. In the presented study, we analysed the hospital stays of patients treated in all hospital wards of the $3^{\text {rd }}$ City Hospital in Łódź during 2012. The following, in particular, were taken into account: admittance procedure, discharge procedure, age and sex of hospitalised persons. Patients in over $55 \%$ of cases were admitted using the sudden admittance procedure. At the same time, over $3 / 4$ of the stays ended with a referral for further treatment in ambulatory conditions, and death occurred in approx. $5 \%$ of hospitalisations. By comparing the discharge procedures, the percentage of deaths in the Anaesthesiology and Intensive Care Wards can be seen clearly (more than 70\%). Internal wards are next in turn (10.6 and 16.6\%). The biggest differences in the length of hospitalisation between the studied institution and the NFZ data (which are averaged values from all medical entities in Poland) concern the E77, A49, A48, A87, A33, D18, E16, E61 and G37 groups.
\end{abstract}

\section{Introduction}

Statistical methods used by healthcare entities enable the collection of various information about the structure and characteristics of treated patients. They are an important source of knowledge, and form a database that plays an important role in entity management theory. Unfortunately, in most cases, due to a permanent lack of time and an accumulation of current affairs, directors who manage hospitals, clinics or laboratories omit the aforementioned methods in daily operation and when making key decisions. As a consequence, they encounter significant problems in the effective analysis of various aspects of the operation of their institutions (Zielinski, 2013).

It should be mentioned that the awareness and understanding of events occurring in the managed healthcare entity enables the optimal manage- 
ment of the given entity, adequate to their capabilities and resources, not only at the given moment, but also in the future due the ability to create forecasts for the future. In the situation where, for the treatment of every patient a specific amount is received (in accordance with the principles established by the NFZ National Health Fund), the issue of correct settlement of services and the possibility of indicating specific reasons, for which one hospitalisation results in losses and another in profits, is the essence of a well-operating entity. Simple statistical analyses provide the answers to basic questions and indicate the reasons for many difficulties which the institutions in question face. They also prove the existence of phenomena, which we may not have been aware of, and act as a bargaining chip in negotiations with supervisory, controlling or founding bodies (Sanak et al., 2010).

As a result of the increasing scope and detail of the data collected by medical entities, we are able to generate reports that a few years ago were out of the realm of possibility. Based on conducted hospital statistics we are able to locate the information that is important from the point of view of individual wards, departments or the management itself. Thus, the variety of conducted analyses is very large. The most known and popular list is a semiannual and annual analysis of hospital activity, containing data about the number of beds, person-days, the number of treated persons, deaths, and mortality and bed occupancy indicator. Systematic analyses are becoming more and more important, e.g.: reasons of patient hospitalisation in individual hospital wards (Kaczor et al., 2011; Rudnicka-Drożak et al., 2010), deaths (Karwat, 2012; Wróblewska et al., 2008) or the average hospitalisation time.

\section{Material and Methods}

All the data concerning the method of treatment of patients admitted to hospital are entered in the institution's IT system. What analyses we have at our disposal and how advanced the lists and comparisons we are able to obtain are dependent on the complexity of a given system and the possibility of extracting the necessary information. In this study, we have analysed the hospital stays of the patients treated at all hospital wards of the $3^{\text {rd }}$ City Hospital in Lodz during 2012. In particular, the following were taken into account: admittance procedure, discharge procedure, and age and sex of hospitalised persons. Pursuant to the settlement data the DRG groups most frequently occurring in the year 2012 were also indicated, and the obtained results were compared with the information provided on the DRG statistics, 2013. For calculations, Excel spreadsheet was used along with 
basic statistical functions, showing that such types of lists do not require complicated software and sophisticated knowledge.

\section{Results}

The obtained results are presented in Tables 1-3 and Figure 1. Tables 13 enable the number of hospitalisations to be established in accordance with procedures of admittance, discharge, sex and age (for the entire hospital) as well as the characterization of specific organisational units, which is more important from the point of view of managers/heads of these organisational cells.

Table 1. Number of hospitalisations in the year 2012 and the percentage of stays divided into procedure of admission and sex of patients

\begin{tabular}{|c|c|c|c|c|c|c|c|c|c|}
\hline \multirow[b]{2}{*}{ Ward } & \multirow[b]{2}{*}{ 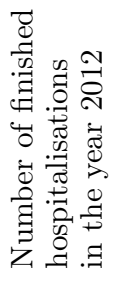 } & \multicolumn{6}{|c|}{ Admittance procedure } & \multicolumn{2}{|c|}{ Sex } \\
\hline & & 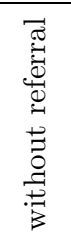 & 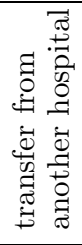 & 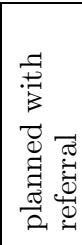 & 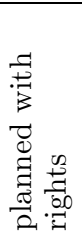 & $\frac{\overrightarrow{0}}{\frac{0}{0}}$ & 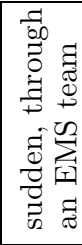 & 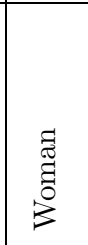 & 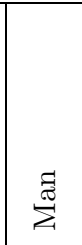 \\
\hline $\begin{array}{l}\text { Anaesthesiology and } \\
\text { Intensive Care }\end{array}$ & 148 & 81 & 3 & 0 & 0 & 13 & 51 & 85 & 63 \\
\hline General surgery & 1783 & 48 & 15 & 403 & 1 & 761 & 555 & 832 & 951 \\
\hline $\begin{array}{l}\text { General surgery } \\
\text { Przyrodnicza street }\end{array}$ & 110 & 0 & 1 & 20 & 0 & 41 & 48 & 51 & 59 \\
\hline $\begin{array}{l}\text { Trauma and Orthopaedics } \\
\text { Surgery }\end{array}$ & 1647 & 13 & 5 & 888 & 1 & 546 & 194 & 941 & 706 \\
\hline $\begin{array}{l}\text { Internal Diseases and } \\
\text { Cardiology }\end{array}$ & 2048 & 161 & 10 & 190 & 687 & 999 & 1 & 1212 & 836 \\
\hline $\begin{array}{l}\text { Operative and Conservative } \\
\text { Gynaecology }\end{array}$ & 341 & 0 & 1 & 274 & 5 & 44 & 17 & 341 & 0 \\
\hline Neurology & 1121 & 111 & 8 & 170 & 2 & 473 & 357 & 622 & 499 \\
\hline Ophthalmology & 1833 & 2 & 0 & 1567 & 1 & 224 & 39 & 1095 & 738 \\
\hline Rehabilitation & 166 & 1 & 0 & 165 & 0 & 0 & 0 & 97 & 69 \\
\hline Neurologic Rehabilitation & 325 & 2 & 0 & 323 & 0 & 0 & 0 & 171 & 154 \\
\hline Stroke & 421 & 58 & 1 & 2 & 0 & 116 & 244 & 255 & 166 \\
\hline Internal A & 1239 & 45 & 2 & 53 & 0 & 383 & 756 & 742 & 497 \\
\hline Hospital Emergency Room & 766 & 0 & 1 & 0 & 0 & 284 & 481 & 482 & 284 \\
\hline Total & 11948 & 522 & 47 & 4055 & 697 & 3884 & 2743 & 6926 & 5022 \\
\hline$\%$ & 100 & 4.37 & 0.39 & 33.94 & 5.83 & 32.51 & 22.96 & 57.97 & 42.03 \\
\hline
\end{tabular}


Aleksandra Sierocka, Bożena Woźniak, Petre Iltchev and Michał Marczak

Table 2. Number of hospitalisations divided by discharge procedure, presented according to individual hospital wards

\begin{tabular}{|c|c|c|c|c|c|c|c|c|c|c|c|}
\hline \multirow[b]{2}{*}{ Ward } & \multicolumn{11}{|c|}{ Discharge procedure } \\
\hline & 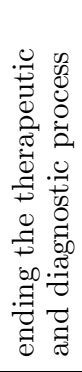 & 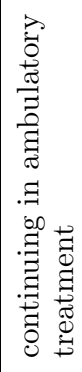 & 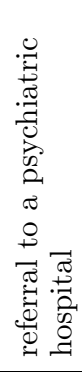 & 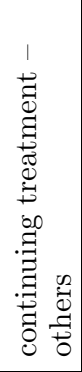 & 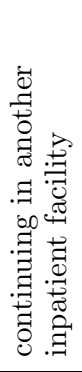 & 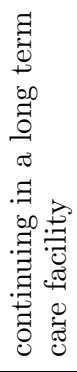 & 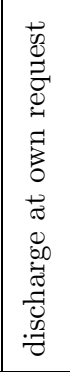 & 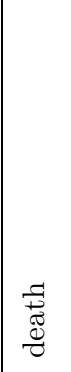 & 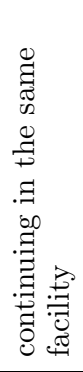 & 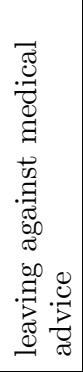 & 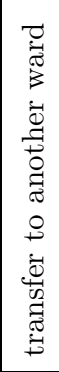 \\
\hline $\begin{array}{l}\text { Anaesthesiology and } \\
\text { Intensive Care }\end{array}$ & 2 & 0 & 0 & 0 & 13 & 0 & 0 & 104 & 0 & 0 & 29 \\
\hline General surgery & 5 & 1547 & 7 & 0 & 15 & 4 & 63 & 75 & 3 & 2 & 62 \\
\hline $\begin{array}{l}\text { General surgery } \\
\text { Przyrodnicza street }\end{array}$ & 14 & 82 & 0 & 0 & 1 & 0 & 6 & 5 & 0 & 0 & 2 \\
\hline $\begin{array}{l}\text { Trauma and Ortho- } \\
\text { paedics Surgery }\end{array}$ & 0 & 1578 & 1 & 1 & 18 & 3 & 9 & 3 & 15 & 0 & 19 \\
\hline $\begin{array}{l}\text { Internal Diseases } \\
\text { and Cardiology }\end{array}$ & 2 & 1610 & 4 & 0 & 109 & 21 & 17 & 216 & 16 & 0 & 53 \\
\hline $\begin{array}{l}\text { Operative and } \\
\text { Conservative } \\
\text { Gynaecology }\end{array}$ & 331 & 4 & 0 & 0 & 4 & 0 & 0 & 0 & 2 & 0 & 0 \\
\hline Neurology & 489 & 443 & 4 & 2 & 35 & 4 & 45 & 17 & 9 & 4 & 69 \\
\hline Ophthalmology & 5 & 1814 & 1 & 3 & 1 & 0 & 3 & 0 & 0 & 0 & 6 \\
\hline Rehabilitation & 2 & 156 & 0 & 0 & 0 & 0 & 3 & 0 & 2 & 0 & 3 \\
\hline $\begin{array}{l}\text { Neurologic } \\
\text { Rehabilitation }\end{array}$ & 4 & 292 & 2 & 0 & 3 & 1 & 8 & 0 & 3 & 0 & 12 \\
\hline Stroke & 129 & 128 & 1 & 0 & 11 & 11 & 10 & 30 & 11 & 0 & 90 \\
\hline Internal A & 0 & 871 & 6 & 1 & 36 & 44 & 28 & 205 & 3 & 0 & 45 \\
\hline $\begin{array}{l}\text { Hospital Emergency } \\
\text { Room }\end{array}$ & 1 & 547 & 0 & 0 & 45 & 3 & 9 & 22 & 4 & 1 & 134 \\
\hline Total & 984 & 9072 & 26 & 7 & 291 & 91 & 201 & 677 & 68 & 7 & 524 \\
\hline$\%$ & 8.24 & 75.93 & 0.22 & 0.06 & 2.44 & 0.76 & 1.68 & 5.67 & 0.57 & 0.06 & 4.39 \\
\hline
\end{tabular}

Table 3. Number of hospitalisations by patients' age

\begin{tabular}{|c|c|c|c|c|c|c|c|c|c|}
\hline \multirow{2}{*}{ All hospital wards } & \multicolumn{8}{|c|}{ Patients' age (in years) } \\
\cline { 2 - 11 } & $18-20$ & $21-30$ & $31-40$ & $41-50$ & $51-60$ & $61-70$ & $71-80$ & $81-90$ & $>91$ \\
\hline Total & 97 & 546 & 691 & 826 & 2012 & 2357 & 2859 & 2339 & 221 \\
$\%$ & 0.81 & 4.57 & 5.78 & 6.91 & 16.84 & 19.73 & 23.93 & 19.58 & 1.85 \\
\hline
\end{tabular}




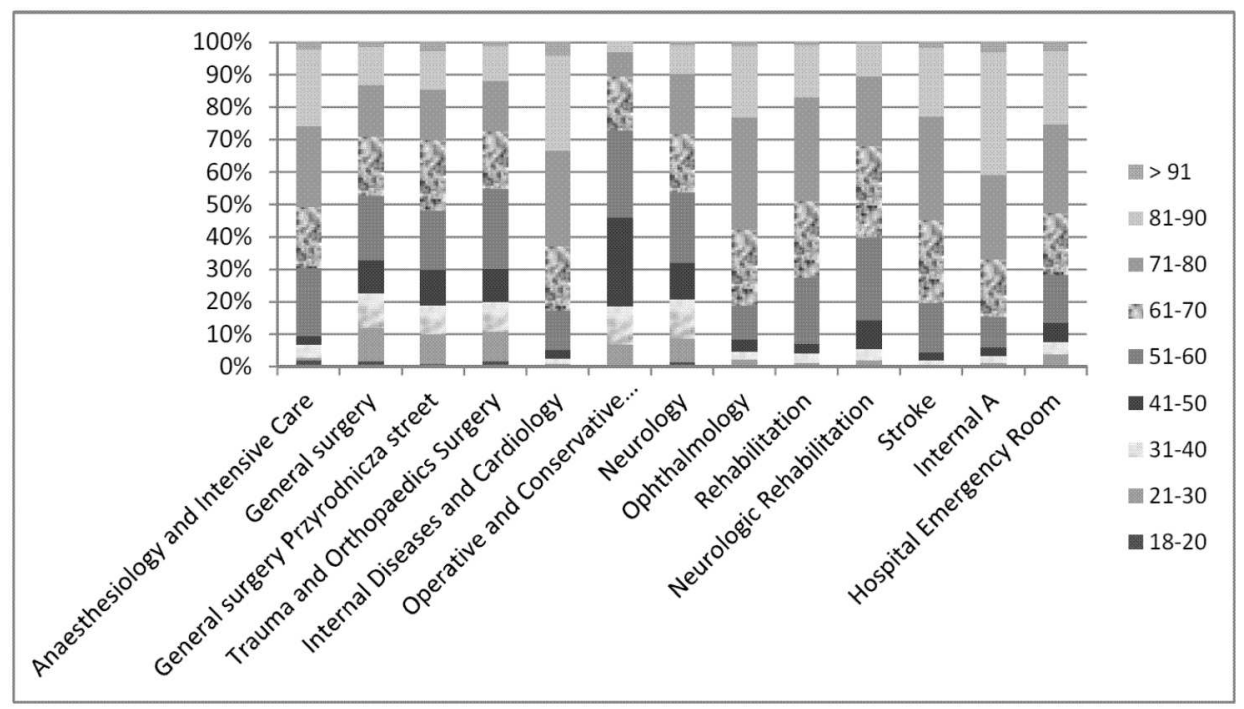

Figure 1. Percentage of hospitalisations by wards, divided by patient's age

Based on the presented data, it is clear that patients in over $55 \%$ of cases were admitted using the sudden admittance procedure (Table 1). This is a significant difficulty for the hospital, since this type of admittance has a much higher risk than planned admittance (which makes up only $1 / 3$ of cases). They require higher financial outlays (i.e., necessary diagnostics and laboratory testing, medical advice, longer hospitalisation time, required transfers between wards etc.) and are highly unpredictable (e.g. due to bad health, co-existing diseases or the patient's age). At the same time, over $3 / 4$ of the stays end with a referral for further treatment in ambulatory conditions, and death occurs in approx. $5 \%$ of hospitalisations (Table 2).

The age of treated patients also has an enormous impact on the hospital's financial condition (the older the person, the more co-existing diseases, the worse their health and the longer the duration of hospitalisation). The results obtained by the study confirm the generally known fact that the society is getting older, and the demand for geriatric wards will be increasing (the group of patients older than 91 years was almost $2 \%$ of the total) (Table 3).

At the same time, the analysis conducted using the criterion of division by wards shows that some of the institution's wards accept most of their patients in a planned manner (e.g. rehabilitation, ophthalmology, gynaecology or orthopaedic) (Table 1). By comparing the discharge procedures, the percentage of deaths in the Anaesthesiology and Intensive Care Wards is 
clearly visible (more than 70\%) (Wróblewska et al., 2008). Internal wards are next in turn (10.6 and 16.6\%) (Kaczor et al., 2011). This type of situation results from the fact that the specifics of each ward vary, in addition to differences in the character of medical services (procedures) provided and the age of hospitalised persons (Figure 1).

The subsequent stage of the analysis was the attempt to indicate DRG groups with the highest significance for the studied entity. Based on the settlement data reported to the NFZ for the year 2012, the most frequent groups were nominated, their percentage share in the total was established, and the median and modal values and average of hospitalisation time were calculated. At the same time, the obtained results were compared with the data provided by DRG statistics, 2013. The complex analysis of the DRG system prepared by the NFZ concerns the services provided within the years 2009-2012 throughout the entire country of Poland. This list includes the number of provided DRG products and the average patient stay time divided by age, sex, admittance and discharge procedure, ICD-10 basic diagnosis and ICD-9 medical procedure for all DRG groups, provided in the years 2009-2012. We will be interested only in the year 2012 .

Due to a high diversity of DRG groups listed by the hospital in the year 2012 , this list refers only to the first 20 items. The results obtained from the studied institution and data from the NFZ system are presented in Table 4.

Analysing the data presented above, it can be clearly seen that the biggest differences in the length of hospitalisation between the studied institution and the NFZ data (which are averaged values from all medical entities in Poland) concern the E77, A49, A48, A87, A33, D18, E16, E61 and G37 groups. For these services, the length of stay of the patient in the studied hospital is approx. 2 days longer than in other institutions. This suggests it may be worth considering why other hospitals are able to treat the patients in a shorter time, and thus to bear lower expenses (for food, drugs, materials, stay etc.).

A significant source of knowledge on hospitalisations is the information on the average time of hospital treatment (separately for each DRG group), listed along with the hospitalisations above a set number of days, which are financed as a group by the NFZ (in accordance with the catalogue of DRG groups). All stays of this extended type should be analysed for the reasons the patient remained in the hospital, and to indicate possible actions that could improve the proceedings in similar cases in the future (complications, adverse event, lack of access to diagnostics, lack of cooperation in transferring of patients to other institutions, e.g. due to lack of space or logistics difficulties) (Podlaski Urząd Wojewódzki w Białymstoku, 2012). 
Table 4. A list of DRG groups most frequently occurring in the studied hospital with the NFZ data (DRG statistics, 2013) for the year 2012

\begin{tabular}{|c|c|c|c|c|c|c|c|c|}
\hline \multirow{2}{*}{\multicolumn{2}{|c|}{ DRG group }} & \multirow{2}{*}{ 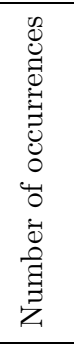 } & \multirow{2}{*}{ 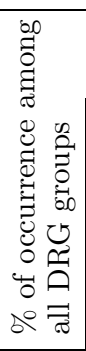 } & \multirow{2}{*}{ 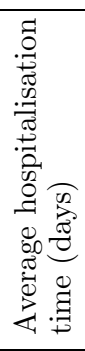 } & \multirow{2}{*}{ 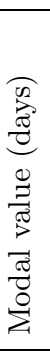 } & \multirow{2}{*}{ 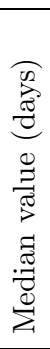 } & \multicolumn{2}{|c|}{$\begin{array}{l}\text { Data from DRG } \\
\text { statistics, } 2013\end{array}$} \\
\hline & & & & & & & & \\
\hline B13 & $\begin{array}{l}\text { Uncomplicated cataract surgery by } \\
\text { emulsification with simultaneous } \\
\text { lens implantation }\end{array}$ & 1024 & 10.27 & 2.61 & 2 & 2 & 0 & 2 \\
\hline E77 & $\begin{array}{l}\text { Other cardiovascular diseases } \\
>17 \text { years of age }\end{array}$ & 569 & 5.71 & 10.94 & 8 & 10 & 7 & 6 \\
\hline A76 & $\begin{array}{l}\text { Head trauma with significant brain } \\
\text { damage, treated conservatively }\end{array}$ & 268 & 2.69 & 4.54 & 2 & 2 & 2 & 3 \\
\hline B12 & $\begin{array}{l}\text { Complicated cataract surgery by } \\
\text { emulsification with simultaneous } \\
\text { lens implantation }\end{array}$ & 256 & 2.57 & 2.96 & 2 & 2 & 2 & 2 \\
\hline H83 & Average procedures on soft tissue & 251 & 2.52 & 3.53 & 1 & 2 & 0 & 2 \\
\hline A 49 & Brain stroke - treatment $>3$ days & 243 & 2.44 & 12.95 & 8 & 11 & 7 & 8 \\
\hline A 48 & $\begin{array}{l}\text { Complex treatment of brain stroke } \\
>7 \text { days on the stroke ward }\end{array}$ & 227 & 2.28 & 15.66 & 10 & 12 & 8 & 10 \\
\hline H62 & $\begin{array}{l}\text { Breaks or dislocations of the pelvis } \\
\text { or lower limb }\end{array}$ & 216 & 2.17 & 9.65 & 4 & 10 & 4 & 8 \\
\hline H33 & Average procedures on lower limb & 178 & 1.79 & 3.19 & 2 & 2.5 & 2 & 2 \\
\hline $\mathrm{A} 87$ & Other nervous system diseases & 170 & 1.71 & 10.39 & 7 & 8 & 2 & 5 \\
\hline A 33 & Balance disorders & 169 & 1.70 & 7.05 & 6 & 6 & 3 & 4 \\
\hline D18 & Atypical viral pneumonia & 166 & 1.67 & 13.51 & 13 & 12 & 7 & 8 \\
\hline B98 & $\begin{array}{l}\text { Conservative ophthalmological } \\
\text { treatment }\end{array}$ & 163 & 1.64 & 6.52 & 1 & 5 & 2 & 3 \\
\hline G34 & $\begin{array}{l}\text { Endoscopic and percutaneous } \\
\text { procedures of bile ducts and } \\
\text { pancreas }\end{array}$ & 159 & 1.60 & 4.50 & 2 & 4 & 1 & 4 \\
\hline E61 & $\begin{array}{l}\text { Heart rhythm disorders }>69 \text { years } \\
\text { of age or with complications }\end{array}$ & 155 & 1.56 & 7.57 & 2 & 7 & 2 & 4 \\
\hline G37 & Acute pancreatitis & 154 & 1.55 & 6.47 & 5 & 5 & 6 & 7 \\
\hline $\mathrm{H} 64$ & Smaller breaks or dislocations & 144 & 1.44 & 2.87 & 1 & 2 & 1 & 1 \\
\hline E16 & $\begin{array}{l}\text { Acute endomyocarditis }>69 \text { years } \\
\text { of age or with complications }\end{array}$ & 140 & 1.40 & 10.98 & 7 & 10 & 4 & 5 \\
\hline F46 & Abdominal diseases & 139 & 1.39 & 5.53 & 2 & 4 & 2 & 3 \\
\hline G25 & Cholecystectomy & 127 & 1.27 & 3.52 & 2 & 2 & 3 & 3 \\
\hline
\end{tabular}




\section{Conclusions}

In summary, we can see how important statistics are, when correctly and systematically kept at medical institutions. The simplest lists and analyses frequently allow the areas that for some reasons generate additional costs to be pinpointed. The knowledge of the entire facility and of the specifics of individual wards provided by prepared reports is an indescribable source of information in an institution's management process. It is the initial point for making key decisions in order to ensure the correct operation of the entire unit, and it enables immediate reaction in crisis situations (e.g. failure of medical equipment, loss of skilled medical personnel).

A hospital, as a whole, will not be able (in the long run) to keep afloat in such difficult times on the medical services market without a thriving department of statistics or analytics. Knowledge from the scope of provided DRG groups and their participation in the costs of the entire contract for hospital treatment enables monthly limits to be planned and problems with both exceeding and not reaching the financial plan to be avoided.

Information for heads of wards/managers of individual departments which enables the characterisation of hospitalised patients, taking into account the age, sex, procedure of admittance and discharge, and the type of medical procedures conducted during the stay, is especially important to enabling the correct organisation of work of medical personnel, to meeting the demand for materials and medicine, or to ensuring free beds for emergency patients.

A series of articles published in journals (Roszkowska et al., 2002) which contain various types of hospital analyses allow for the establishment of what information is of interest to the decision-makers in other hospitals, as well as the possibility to compare the results of the given entity with the data from other institutions (Narodowy Fundusz Zdrowia, Departament Świadczeń Opieki Zdrowotnej, 2012).

\section{R E F E R E N C E S}

DRG statistics. (2013). Retrieved from http://prog.nfz.gov.pl/app-jgp/.

Kaczor, I., Lolo, A., Pakieła, O., Wójcik, D., Zajbt, M., \& Wełnicki, M. (2011). The most frequent causes of hospitalizations of patients over 90 years old in the internal diseases ward. Gerontologia Polska, 19(3-4), 146-149.

Karwat, K. (2012). Analiza przyczyn zgonów w klinice pneumonologii. Polski Merkuriusz Lekarski, XXXII(190), 221-224. 
Narodowy Fundusz Zdrowia, Departament Świadczeń Opieki Zdrowotnej. (2012). Analiza świadczeń zdrowotnych w latach 2009-2011 w rodzaju: lecznictwo szpitalne. Retrieved from http://www.nfz.gov.pl/new/art/5059/2012_08_24_ analiza_SZP.pdf.

Podlaski Urząd Wojewódzki w Białymstoku. (2012). Analiza działalności leczniczej $w$ rodzaju stacjonarne $i$ całodobowe - szpitalne świadczenia zdrowotne w województwie podlaskim w 2011 roku. Retrieved from http://www.bialystok.uw. gov.pl/NR/rdonlyres/9347A161-8C36-4BE4-AC48-0758FA55C10F/24124/ Analizadzia\%C5\%82alno\%C5\%9Bcileczniczejwrodzajustacjonarneic.pdf.

Roszkowska, H., Chańska, M., \& Seroka, W. (2002). Hospital morbidity in mazovian Voivodeship in the first year of the new health care system. Przeglad Epidemiologiczny, 56, 151-158.

Rudnicka-Drożak, E., Rybojad, B., Jaworska, I., Korecka, R., \& Aftyka, A. (2010). Analysis of the causes of hospitalization in the Intensive Care Unit of the Regional Specialist Hospital in Lublin. Polish Journal of Public Health, 120(1), 29-32.

Sanak, U., Młynarczyk, A., \& Karbarz, K. (2010). Raport Lecznictwo szpitalne w Małopolsce 2009. Kraków: Departament Zdrowia i Polityki Społecznej UMWM.

Wróblewska, K., Jaszewski, M., Chilińska, J., Krajewska-Kułak, E., Jankowiak, B., Kowalewska, B., \& Golębiewska, A. (2008). The analysis of the most frequent causes of death of patients in the Cardinal Stefan Wyszynski Provincial Hospital in Łomża - preliminary study. Problemy Higieny $i$ Epidemiologii, 89(1), 136-141.

Zieliński, T. (2013). Statystyka w zarządzaniu placówkami medycznymi, Retrieved from http://www.statsoft.pl/czytelnia/medyczne/wzarzadzaniu.html. 